\title{
NOTES
}

\section{UNION RIGHT OF REPLY TO EMPLOYER ON-THE-JOB SPEECHES: THE NLRB TAKES A NEW APPROACH*}

SECTION $8(1)$ of the Wagner Act branded employer interference with employees' right to self-organization an unfair labor practice. ${ }^{1}$ Interpretation of this provision gradually permitted employer indulgence in general noncoercive propaganda against unionization, but barred utterances found part of a coercive course of conduct or embodying actual or implied threats of economic reprisal. ${ }^{2}$ And in 1946, the NLRB's Clark Bros. decision held that employers' anti-union speeches to compulsorily assembled employees on company time and premises violated their freedom to determine whether or not to receive advice concerning their right to self-organization. ${ }^{8}$ Illegalization of "captive audience" speeches deprived employers of an effective technique for influencing employees' votes in NLRB representation elections.

*Bonwit Teller, 96 N.L.R.B. No. 73 (Oct. 4, 1951) ; Biltmore Manufacturing Co., 97 N.L.R.B. No. 128 (Dec. 31, 1951).

1. Section 8(1) of the NLRA, popularly known as the Wagner Act, made it an unfair labor practice for an employer to "interfere with, restrain, or coerce employees in the exercise of the rights guaranteed in section 7." 49 STAT. 452 (1935), 29 U.S.C. \$ 158(1) (1946). Section 7 provides that "[e]mployees shall have the right to self-organization, to form, join, or assist labor organizations, to bargain collectively through representatives of their own choosing. . ." 49 STAT. 452 (1935), 29 U.S.C. \& 157 (1946). Taft-Hartley left the quoted portions of these sections unchanged.

2. E.g., NLRB v. American Tube Bending Co., 134 F.2d 993 (2d Cir. 1943), cert. denied, 320 U.S. 768 (1944) ; Oval Wood Dish Corp., 62 N.L.R.B. 1129, 1138 (1945). During the first years of Wagner Act administration, however,..the NLRB had decmed almost any employer anti-union expression a violation of $\$ 8(1)$. Employee fear of economic retribution was thought to automatically lend any "preferential" statement a coercive effect. For the classic statement, see NLRB v. Federbush Co., 121 F.2d 954, 957 (2d Cir. 1941).

For discussions of these gradual developments under the Wagner Act, see 2 Tellek, Labor Disputes and Collective Bargaining $\$ \S 252,286$ (1940) (Supp. 1947); Daykin, Employer's Right of Free Speech in Industry under the NLRA, 40 ILL. L. REv. 185 (1945) ; Morgan, Employer's Freedom of Speech and the Wagner Act, 20 Tulane L. Rev. 469 (1946) ; Comment, 34 CALIF. L. REv. 415 (1946). For valuable collection of cases, see the NLRB's Annual Reports.

3. 70 N.L.R.B. 802 (1946). Employer compelled its employees to assemble during working hours to hear its anti-union campaign speeches broadcast throughout the plant an hour before a representation election. Convening of a "captive audience" by employercontrol of working hour activities was held a per se violation of $\S 8(1)$.

Prior to Clark Bros., compulsory attendance at anti-union meetings was deemed an element of a coercive course of conduct. Thompson Products, Inc., 60 N.L.R.B. 1381, 1385 (1945); Van Raalte, Inc., 69 N.L.R.B. 1326, 1333 (1946). But sec dicta in NLRB v. 
The Taft-Hartley Act, however, caused a re-evaluation of permissible employer speech. Directed in part against the NLRB's Clark Bros. holding, Section 8 (c) provided that the "expressing of views ... shall not constitute ... an unfair labor practice ... if such expression contains no threat of reprisal, or force or promise of benefit."4 Before the effective date of the Act, the Second Circuit affirmed the Clark Bros. decision, but modified the Board order to permit the employer to address his employees on company time and property, provided the union was accorded a similar opportunity. ${ }^{5}$ Confronted with Section S(c) and its legislative history, however, the NLRB disregarded the Second Circuit opinion and soon abandoned the "captive audience" con-

Montgomery Ward \& Co., 157 F.2d 486, 498 (8th Cir. 1946) (one month after Clarl: case), reversing 64 N.L.R.B. 432 (1945). The Board had found the speech coercive in a context of discriminatory discharges. With the discharges upheld, that finding was necessarily reversed. See 12 NLRB ANN. Rep. 49 (1947). For case classification, see Note, 25 N.C.L. REV. 216, 224 (1947).

4. Labor-Management Relations Act, 61 StAT. 136 (1947), 29 U.S.C. \$141 et seq. (Supp. 1951) ("Taft-Hartley Act"). Section S(c) reads in full: "The expressing of any views, argument, or opinion, or the dissemination thereof, whether in written, printed, graphic, or visual form, shall not constitute or be evidence of an unfair labor practice under any of the provisions of this Act, if such expression contains no threat of reprisal, or force or promise of benefit." 61 STAT. 142 (1947), 29 U.S.C. $\$ 158(c)$ (Supp. 1951).

"The Board has place a limited construction upon [Supreme Court decisions guaranteeing employer free speech] by holding such speeches by employers to be coercive if ... the speech was made in the plant on working time (Clark Brothers, 70 N.L.R.B. 60 (1946)). The committee believes these decisions to be too restrictive. ..." SE:. REP. No. 105, 80th Cong., 1st Sess. 23, 24 (1947), accompanying the Taft-Hartley Act. For Congressional history of $\S S(c)$ with majority and minority views on the permissible content of employer anti-union expressions; the status of speech as part of "coercive course of conduct"; and evidential admissibility of privileged statements to prove motive for discriminatory discharges; see H.R. REP. No. 245, S0th Cong., 1st Sess. 23-4, 35, 41 (1947); SEN. ReP. No. 105, S0th Cong., 1st Sess. 33, 54, 84 (1947) ; H.R. Rep. No. 510, 80th Cong., 1st Sess. 8, 45 (1947). Also see 13 NLRB ANn. Rep. 49 (194S); and, e.g., NLRB v. Kropp Forge Co., 178 F.2d 822 (7th Cir. 1949), cert. denied, 340 U.S. 810 (1950). For analysis, see 2 TELLER, op. cit. supra note 2 , $\$ \$ 398.105-7$ (1950) ; Burstein, Free Specch for Employers, 1 LABOR L.J. 425 (1950); Cox, Some Aspects of the Labor Mantagenemt Relations Act, 61 Harv. L. Rev. 1, 15-20 (1947) ; Daykin, The Employers' Right of Free Speech Under the Taft-Hartley Act, 37 Iowa L. Rav. 212 (1952) ; Herzog \& Rikoon, The Employer and the First Amendment, 22 ST. JoBN's L. REv. 109 (1947); Rose, Frecdom of Speech for Employer and Employee, 35 A.B.A.J. 637 (1949) ; Comment, 2 SoltuwEster: L. J. 159 (1948).

5. NLRB v. Clark Bros., 163 F.2d 373 (2d Cir. July 29, 1947). Section \&(c) tool: effect on Aug. 22, 1947, 60 days after enactment on June 23, 1947.

"An employer has an interest in presenting his views on labor relations to his employees. We should hesitate to hold that he may not do this on company time and pay, provided a similar opportunity to address them ace accorded representatives of the strion. ... NLRB v. Clark Bros., 163 F.2d 373, 376 (emphasis added).

The court's decree enforcing the Board order modified its protisions against "ecmpelling ... employees during working time to listen to speeches telating to self-organization ..." by adding "without according similar opportunity to address them to the Union." 12 NLRB ANN. REP. 49 (1947). 
cept. $^{6}$ And in S\&S Corrugated Paper Machinery Co., the Board specifically held that employers could make non-coercive anti-union speeches to assemblages of company employees during working hours without granting the union an equivalent opportunity to reply. ${ }^{\text {? }}$

In the recent Bonwit Teller decision, ${ }^{8}$ however, the NLRB overruled the Corrugated case ${ }^{9}$ and took a new approach to employer speeches on company time and premises. Bonwit Teller had enforced the broad no-solicitation rule permitted by the NLRB in retail department stores. Intended to prevent disruption of business, this company rule forbids union activity at any time on the selling floor. ${ }^{10}$ But six days before a run-off representation election, the

6. In Babcock \& Wilcox, 77 N.L.R.B. 577, 578 (May 13, 1948), 48 CoL. L. REv. 1098 (1948), the Board held that "The language of $8(c)$... and its legislative history, makes it clear that the [compulsory audience] doctrine of the Clark Bros. case no longer exists as a basis for finding unfair labor practices. ..." Subsequent cases agreed. E.g., Fontaine Converting Works, 77 N.L.R.B. 1386 (1948); Hinde \& Dauch Paper Co., 78 N.L.R.B. 488, 489 (1948) ; Kentucky Utilities Co., 83 N.L.R.B. 981,982 (1949); Charroin Mfg. Co., 88 N.L.R.B. 38,40 (1950).

Even before the Board in Babcock \& Wilcox had abandoned the "captive audience" doctrine, commentators deemed it "plainly overruled" by $\S 8(\mathrm{c})$. Cox, sipra note 4 , at 15 .

7. 89 N.L.R.B. 1363,1364 (1950).

Prior to Babcock \& Wilcox, supra note 6, in Merry Bros. Brick \& Tile Co., 75 N.L. R.B. 136, 138 (Oct. 27, 1947), the effect of $\S 8(c)$ on the Trial Examiner's "captive audience" finding was not reached. The Board construed the Second Circuit's opinion in the Clark case as requiring a union request for the similar opportunity to address the employees, which request was not proven in the case at hand. In a later case, findings by a Trial Examiner that "it appeared no similar opportunity was granted to the labor organization to address the employees," without finding a union request, were not relied upon. Loudenville Milling Co., 79 N.L.R.B. 304, 307, 322 (1948). No union reply requtest appeared in any "captive audience" case until S\&S Corrugated.

8. 96 N.L.R.B. No. 73 (Oct. 4, 1951).

9. "To the extent that our decision herein may be deemed to be inconsistent with the Board's decision in S\&S Corrigated Paper Machinery Co. Inc., 89 NLRB 1363, that decision is hereby overruled, but Babcock $\mathcal{E}$ Wilcox is adhered to." Bonwit Teller, 96 N.L.R.B. No. 73, p. 9, n.12 (Oct. 4, 1951) (mimeo).

10. In judging the validity of company restrictions on union activity, the NLRB must balance the property rights of the employer and his interest in efficient production and discipline against employee rights of self-organization. Contentions that the Fifth Amendment protects the employer against any interference with his property rights have beell rejected. Republic Aviation Corp. v. NLRB, 324 U.S. 793, 802 (1945); NLRB v. Cities Service Oil Co., 122 F.2d 149, 152 (2d Cir. 1941) ; cf. Marsh v. Alabama, 326 U.S. 501, 505-6 (1946).

Company no-solicitation rules forbidding union organizing activity during working hours are presumed valid if not applied in a discriminatory manner. E.g., Jaques Power Saw Co., 85 N.L.R.B. 440, 444 (1949). Rules restricting solicitation of union memberships on company property during non-working hours are presumed invalid, as a violation of $\S 8$ (a) (1), in the absence of special circumstances. Republic Aviation Co. v. NLRB, supra; Peyton Packing Co., 49 N.L.R.B. 828, 843 (1943), enforcement granted, 142 F.2d 1009 (5th Cir. 1944), cert. denied, 323 U.S. 730 (1945) ; 1. F. Sales Co., 82 N.L.R.B. 137, 138 (1949) (paid luncheon and rest periods not "working time"). Such special circumstances exist in department stores which, because of the presence of customers, may forbid union 
store closed its doors a half-hour early and instructed its employees to assemble on the main selling floor. ${ }^{11}$ Although the company's president presented arguments against voting for the Retail Clerks' International Association, a union request for an equivalent opportunity to address the employees on company time and premises was denied. ${ }^{12}$ The union lost the election and protested to the NLRB. Sidestepping the "captive audience" problem, 13 the Board, salvaging the Second Circuit's Clark Bros. doctrine, ${ }^{14}$ held the denial of the union's reply request an unfair labor practice, and set the election aside.

activity at any time on its selling floors. Solicitation, even during employees' off-duty time, may there disrupt business. E.g., May Department Stores Co., 59 N.L.R.B. 976, 981 (1944), enforcement granted, 154 F.2d 533 (Sth Cir. 1946) ; Marshall Field \& Co., 98 N.L.R.B. No. 11 (Feb. 15, 1952) (good review of permissible extent of rule with clarification of right of non-employee organizers to solicit off-duty employees in non-selling areas of the store).

No-solicitation rules were not affected by the Taft-Hartley Act. 13 NLRB Arm. Rap. 52 (1948).

For more detailed review of no-solicitation rules, see Daylin, Employecs' Right to Organize on Company Time and Property, 42 ILL. L. Rev. 301 (1947); Note, 26 Ore. L. REv. 298 (1947).

11. The previous election had not resulted in a majority vote for either of the two contesting unions or the "no-union" choice. The Amalgamated Clothing Workers, C.I.O. received the least votes and was eliminated, and the Board directed a run-ofi election between the Retail Clerks' International Association, AFL, and "no-union" to be held September $15,1949$.

12. "On September 12,1949, the RCIA wrote to the Respondent requesting an opportunity to address the employees under conditions comparable to those under which Rudolph's speech was delievered. The Respondent did not achrowledge this letter." Intermediate Report, p. 4, Bonwit Teller, 96 N.L.R.B. No. 73 (Oct 4, 1951).

13. Since convoking a "compulsory" audience is no longer unlawful, see note 6 sufpr, the Trial Examiner found it unnecessary to resolve the conflict in evidence as to whether or not employees were forced to attend the meeting. Id. at 11. The Board agreed, not finding "illegal ... the manner in which (the employer) assembled its audience." Bonwit Teller, 96 N.L.R.B. No. 73 at p. 10.

Refusal to find a "captive audience" illegal per se rests on statutory interpretation founded only on $\$ \$(c)$ legislative history condemnation of the Board's Clarl Bros. decision and on modification of that decision by the Second Circuit. See notes 4, 5 supro. The First Amendment would probably not protect speech delivered to an involuntary audience. "The right of free speech is guaranteed to every citizen that he may reach the minds of willing listeners. . . To enforce freedom of speech in disregard of the rights of others would be harsh and arbitrary in itself." Justice Reed in Kovacs v. Cooper, 336 U.S. 77,78 (1949) (emphasis added) (upholding a city ordinance which forbade sound truels on the public streets, as applied to speeches on a labor dispute). But cf. Pub. Util. Comm. v. Pollak, 20 U.S. L. WeEk 4343 (May 27, 1952) (music and non-controversial spot announcements to bus passengers held constitutional); and see NLRB v. Miontgomery Ward, 157 F.2d 486, 499 (8th Cir. 1946) (labor "captive audience" permissible; "First Amendment is concerned with the freedom of thought and expression of the spealser or writer, not with conditions under which the auditor or listener receives the message"). See note 3 supra and Notes, 15 Geo. WASH. L. Rev. 367 (1947); 16 Ford. L. Rer. 135 (1947).

14. See note 5 supra. For argument that the relevant portion of Clorl: Bros. was mere dictum in addition to being otherwise inapplicable, see Bonwit Teller, 96 N.L.R.B. Nu. 73 , p. 14 (Oct. 4, 1951) (dissenting opinion). For the majority's refutation, see id. at "y, n.13. 
The Board's decision relied on two separate grounds. Under the narrower rationale, refusal to permit the union rebuttal resulted in discriminatory application of an otherwise valid no-solicitation rule. ${ }^{15}$ Settled doctrine prevents an employer from applying the rule in such a way as to favor one union over another, or to preclude union solicitation while permitting anti-union employees or third parties to campaign freely. ${ }^{16}$ Logically, the Board majority reasoned, the rule is discriminatorily applied as well when employers campaign on company premises while denying unions the same privilege. ${ }^{17}$ Uncler the Board's "more fundamental consideration," moreover, the right of employees

15. Id. at 4 .

16. Although a no-solicitation rule is valid on its face, the discriminatory promulgation or application of such rules violates $\S 8(\mathrm{a})$ (1). See note 10 supra and articles cited.

The employer may not restrict solicitation of its employees on company time or property while permitting similar activity by adherents of a more-favored union. NLRB v. Waterman Steamship Corp., 309 U.S. 206, 222 (1940) ; Bingham's Son Mfg. Co., 80 N.L. R.B. 1612, 1613 (1948) (AFL on-the-job speech invited while CIO organizing activity prohibited). Nor may campaigning by anti-union employees be permitted while a pro-union activity ban is enforced. NLRB v. Harbison-Walker Co., 135 F.2d 837 (8th Cir. 1943); Lindley Box and Paper Co., 73 N.L.R.B. 553, 554 (1947) (working hour meeting by antiunion employees). Permitting anti-union activity on company property by town businessmen while denying the same privileges to pro-union campaigning is also illegal. NLRB v. American Furnace Co., 158 F.2d 376, 379 (7th Cir. 1946).

17. Employer prohibition of pro-union activity on company time and premises while permitting anti-union activity thereon clearly violates $\S 8(a)(1)$. See notc 16 supra. But until Bonzwit Teller, holdings (on whether anti-union campaigning by the employer itself came within the scope of company no-solicitation rules) were confused.

Employer anti-union speechmaking and leaflet distribution during working hours despite his ban on pro-union activity was held discriminatory conduct by a Trial Examiner, and affirmed by the Board without comment. Goodall Co., 86 N.L.R.B. 814, 841 (1949). But the five judicial authorities cited all involved the employer's permitting employee or third party activity.

Aside from Goodall, supra, the only instances where campaigning by management itself was held violative of company no-solicitation rules involved supervisors who circlllated employee petitions repudiating the union. Kentucky Utilities Co., 83 N.L.R.B. 981, 982 (1949) ; Allen-Morrison Sign Co. Inc., 79 N.L.R.B. 904, 905 (1948) ; Macon Textiles, Inc., 80 N.L.R.B. 1525, 1527, 1550 (1948); Editorial 'El Imparcial' Inc., 92 N.L.R.B. 1790,1796 (1951). A possible explanation of these cases may be that "employer soliciti" tion of employees to repudiate their union are coercive per se and are not protected by $\S 8$ (c) as an expression of 'views, arguments and opinions.'" Kentucky Utilities Co., supra at 982.

Both before and after Goodall, employer campaigning was considered from the view* point of permissible speech. Its relationship to no-solicitation rules was disregarded even where other discriminatory violations of that rule were found. E.g., NLRB v, Winona Knitting Mills, Inc., 163 F.2d 156 (8th Cir. 1947); Lindley Box \& Paper Co., supra note 16; Salant \& Salant, 92 N.L.R.B. 343, 356 (1950) ; Grove Regulator Co., 66 N.L.R.B. 1102,1104 (1946) (all involving employer speeches on company time and property); and Salant \& Salant, 92 N.L.R.B. 417 (1950) (supervisor's remarks). Even where employer circulation of anti-union petitions was held a discriminatory violation of a no-solicitation rule, Allen-Morrison Sign Co., supra, an anti-union employer speech was not so tested. And in Fontaine Converting Works, Inc., 77 N.L.R.B. 1386, 1387 (1948), involving a 
freely to select or reject union representation includes the right to hear both sides under conditions reasonably approximating equality. ${ }^{18}$ And in the circumstances present in the case, only the employer's approval of the union's request for a reply speech could have achieved that equality. ${ }^{10}$ The broad nosolicitation rule had drastically curtailed union contact with employees $;^{20}$ the proximity of the speech to election day had limited any rebuttal opportunities by ordinary union organizational techniques; $;^{21}$ other unfair labor practices had occurred, including a "promise of benefit," unprotected by $\$ \&(c)$, in the employer's speech, found to hamper further the employees' freedom of choice. $^{22}$

speech to a compulsory audience, the employer himself attempted to prove the existence of a no-solicitation rule to justify other conduct.

Board Miember Reynolds, dissenting in Bonarit Teller, was thus substantially correct in maintaining that "[i]n the past, the Board has not held that an employer's privilege of fair comment to all his assembled employees concerning a forthcoming clection was circumscribed by the restrictions inherent in no-solicitation rules." 96 N.L.R.B. No. 73, p. 12. His contention that $\S \&(\mathrm{c})$ prevents a change in that policy seems less supportable. Sce note 46 infra. The Bonzerit Teller majority has clarified the previous confusion by a more realistic attitude that employers may not exempt themselves from their own clection campaign rules.

18. 96 N.L.R.B. No. 73, p.6. While the right of information is not referred to specifically among the employees' right to self-organization as guaranteed by $\$ 7$, that section was read to include "the full freedom to receive aid, advice and information from others concerning their rights and their enjoyment." Harlan Fuel Co., 8 N.L.R.B. 25, 32 (1938).

Bonzwit Teller's inclusion of equal opportunity to hear both sides as a cuncomitant of the employees' right of information accords with democratic ideas of free choice based on an informed electorate. Furthermore, the NLRB has been reluctant to set aside an election on inaccurate, untrue or exaggerated campaign propaganda grounds, and leaves to the interested parties a counteracting function. See 14 NLRB Arisi. Rep. 29 (1949); 15 NLRB ANw. REP. 83 (1950). The parties, of course, cannot perform that function if employees can hear only one side.

19. Bonwit Teller, 96 N.L.R.B. No. 73, p.7.

20. "Whatever opportunity that the Union may have had to solicit employees outside of the store or at union meetings, it is clear that the Respondent's broad no-solicitation rules had deprived RCIA of the most effective means of contact with employees-namely, solicitation of employees while they were in the store." Ibid.

21. Ibid. The dissent, however, maintained that the speech six days before the election gave "ample time for RCIA to reply-if opportunity to reply be deemed imperativethrough usual union channels of communication, namely, campaign lezilets or union hall addresses." Id. at 14. For editorial approval of this position, see N.Y. Times, Oet. 5, 1951, p. 26, col. 2; and David Lawrence, N.Y. Herald Tribune, Oct. 9, 1951, p. 4, col. 1. Sce notes 33-7 inifra.

22. References in the president's speech to pending vage increases to be forthcoming after the election without the need for the RCIA were held to violate $\$ 8(a)$ (1) as a "promise of benefit" not protected by $\S 8(c)$. Bonvit Teller, 96 N.L.R.B. No. 73, p. 3. Statements by supervisory employees that wage increases would be further deferred if RCIA won the election, and that favorable wage, promotion and layoff policies would be retracted were also held unfair labor practices interfering with a frce choice in the election. Id. at 4. But all other arguments in the president's on-the-job speeches as well as in the company anti-union leaflets were held within the privileged category of $\$ S(c)$ free speech. Intermediate Report, Bonwit Teller, supra, at 7. 
While the Board failed to delineate the particular circumstances demanding equal opportunity to be heard in other fact situations, ${ }^{23}$ its recent decision in Biltmore Manufacturing Co. ${ }^{24}$ throws some light on the Bonwit Teller ruling. The plant manager of Biltmore, an industrial concern, spoke against the United Textile Workers to his assembled employees on company time only two hours before a-decertification election. ${ }^{25}$ At this meeting he refused to permit an answer by one of the employees present. The union lost the election, and complained in representation proceedings before the Board. Unlike Bonwit Teller, the record showed neither a general no-solicitation rule nor a background of unfair labor practices. Nevertheless, the Board set the election aside, ${ }^{26}$ relying mainly on the employer's refusal to accord the union a chance

23. See discussion of Bonwit Teller in 28 LAB. Ret. REP. (Analysis) 105 (Oct. 8, 1951), stressing the uncertain consequences of the decision. In fact, a Regional NLRB Director upheld a consent election over union objections that opportunity to reply to an employer speech delivered on company time and premises the day prior to the election hat been denied. He stressed absence of a strictly enforced no-solicitation rule in respondent department store and lack of a background of unfair labor practices to distinguish Bonvit Teller. England Brothers, Inc., 29 LAB. ReL. Rep. 93 (Dec. 13, 1951). On the basis of Biltmore Manufacturing Co., 97 N.L.R.B. No. 128 (Dec. 29, 1951), the Regional Director subsequently reversed himself and set aside the election results. 29 LAD. REL. REP. 128 (Jan. 14, 1952).

24. 97 N.L.R.B. No. 128 (Dec. 29, 1951).

25. Decertification petitions, asserting that the currently recognized union no longer represents a majority of the employees, may be filed by employees under $\$ 9$ (c)(1)(A) (ii) of the Taft-Hartley Act.

26. Also, unlike Bonweit Teller, no unfair labor practice proceeding was instituted to complement this representation case. Billmore may not be regarded as precedent for future unfair labor practice cases since "conduct that creates an atmosphere which renders improbable a free choice will sometimes warrant invalidating an election, even though that conduct may not constitute an unfair labor practice." General Shoe, 77 N.L.R.B. 124, 126 (1948), 58 Y ALE L.J. 165. (1948) (Section 8(c) applies only to unfair labor practices, not representation cases; extreme anti-union employer campaign methods, privileged against the unfair labor practice charge, warranted setting the election aside). Accord, Metropolitan Life Insurance Co., 90 N.L.R.B. 935, 938 (1950). Nevertheless, the NLRB relies sparingly on this dichotomy, repeatedly distinguishing General Shoe and utilizing standards for setting aside an election for employer anti-union campaigning largely coinciding with those in a $\S 8(\mathrm{a})$ (1) unfair labor practice proceeding, including $\$ 8(\mathrm{c})$ defenses. E.g., Mallinckrodt Chemical Works, 79 N.L.R.B. 1399 (1948) ; Hinde \& Dauch Paper Co., 78 N.L.R.B. 488 (1948). See Míllis \& Brown, From the Wagner Act to TAFT-HARTLLY 526-8 (1950).

And, no language in the Biltmore opinion implies a limitation to representation proceedings. On the contrary, $\S 8(\mathrm{c})$ defenses were allowed, and a violation of $\S 7$, which constitutes an unfair labor practice, was found.

That no unfair labor practice proceeding took place is probably duc to current NLRB policy of granting precedence to election cases over certain types of unfair labor practice cases. The Board thus "sacrifices" the latter because of increasing rate of cases handled by a smaller staff. 22 LAB. REL. REP. 225 (Mar. 17, 1952). The same reason probably explains lack of unfair labor practice proceedings supplementing later representation cascs relying on the Bonwit Teller and Biltmore union right of reply. Bernadin Bottle Cap Co., 
to reply at the meeting as a denial of equal opportunity ${ }^{2 \pi}$ under the Borrarit Teller holding.

The Board's Biltmore opinion, however, does not establish factual criteria for deciding when an employer must grant a request for a union reply tall:. That some form of adequate union reply to an employer speech must be available is clear from the holding. ${ }^{2 s}$ But the majority's reasoning pointed to the two-hour time factor as making a rebuttal talk at the employer meeting the only adequate form of union reply. ${ }^{29}$ Narrowly read, therefore, when the union has more time for effective rebuttal, Biltmore might be satisfied by a union reply through a medium other than an on-the-job talk. The tenor of the Board's opinion, however, favors a broader view, independent of any consideration of time: whenever pending a representation election ${ }^{20}$ the $\mathrm{em}$ ployer addresses his employees on company time and premises, equality of opportunity demands that the union be permitted to reply by a speech under equivalent conditions. ${ }^{31}$

97 N.L.R.B. No. 241 (Feb. 5, 1952) ; Belknap Hardware \& Mfg. Co., 98 N.L.R.B. No. 89 (Mar. 10, 1952). Representation cases can not result in cease and desist orders, which are limited by $\S 10$ to unfair labor practices. But since failure to file an unfair labor practice charge in these cases was probably discretionary, such proceedings would quiclily ensue if the employer continued his proscribed conduct.

27. Analogy was also made to the Bonswit Teller alternative ground of discriminatory violation of a no-solicitation rule. Even though a no-solicitation rule did not here exist, the Board invoked the same legal consequences: "[I]n either case, the Employer is discriminating in favor of anti-union adherents to the serious detriment of union adherents." Biltmore Manufacturing Co., 97 N.L.R.B. No. 12S, p. 3 (Dec. 29, 1951).

28. Since the speech was made just two hours beiore the election, "[t]here was no opportunity for the union adherents to reply other than in the manner requested." Ibid. See note 49 infra.

29. See note 28 supra.

30. It is doubtful whether an equal opportunity rule applies to non-representation union problems. Anchor Rome Mills, 86 N.L.R.B. 1120 (1949) (refusal to permit union reply to employer on-the-job speech in organized plant concerning impending strilie held lawful; majority status of union as collective bargaining representative never questioned by employer), was cited by the Bonurit Teller dissenting opinion together with the $S \& S$ Corrugated case, see text at note 7 supra, as precedents contrary to the majority proposition. While $S$ \& $S$ Corrugated was overruled, see note 9 sispra, the Bonarit Teller majority made no reference to the Anchor Rone Mills case, probably indieating that a recognized union whose collective bargaining status is unchallenged has better opportunity to convey its views to its own members than a union struggling to contact employces unfamiliar with its policies and rendered hostile by employer propaganda.

Once a plant has been organized, the presence of official union shop stewards among the workers may be the most effective union method of communication, eliminating the need for a union reply speech. See Baker, Ballantixe \& True, Transantming Imrosjation Througe Managenent and Union Channels 53, 60, 109 (1949) (hereinaiter cited as Bafer, Ballantine \& True); Peters, Cosarunications Wital: Industry 131 (1949). In fact, one expert has stated that "[t]he organizcd wage-earner usually gets more information from his union than from management" Dodge, Conecraing Pullic Relations and the Labor Qucstion, 7 PUB. Rer. J. 3, 4 (Mar. 1951) (emphasis added).

31. "The employer dedicated company time and property to a campaign against the union, while refusing to accord the tution an opportmity to reply undor equal circust:- 
Since no other real campaign equivalent to employer speechmaking during working hours is open to a union, ${ }^{32}$ broad reading of Biltmore better implements the "equal opportunity" rule. Psychological tests indicate that leaflets or other printed propaganda devices cannot match the persuasive power of oral presentations $; 3$ and printed material can reach only a small minority of the full audience guaranteed the employer by his control over working time. ${ }^{34}$ Union meetings to organize employees tired from their day's work and faced with

stances.” Biltmore Mfg. Co., 97 N.L.R.B. No. 128, p. 4 (Dec. 31, 1951) (emphasis added). The dissent ascribed this broad view to the majority.

Also, subsequent to Biltmore, the Board has required union replies to employer on-thejob speeches made the same day as the election without specifying the number of hours, Belknap Hardware \& Mfg. Co., 98 N.L.R.B. No. 88 (Mar. 10, 1952); and the day before election, Bernadin Bottle Cap Co., 97 N.L.R.B. No. 241 (Feb. 5, 1952). As in Billmorc, the Board apparently made no attempt to evaluate or even ascertain any feasible alternative campaign media.

32. See notes 33-7 infra.

33. See Klapper, The Efrects of Mass Media pt. 2, p. 10 (1949). For typical testing procedures and findings, see Wilke, An Experimental Comparison of the Speech, the Radio, and the Printed Page as Propaganda Devices in Arcuives of Psycholocy No. 169 (Columbia University Press 1934). Election speechmaking even where transmitted by radio was more effective than newspapers because of the more personal relationship between speaker and audience. Lazarsferd, Berelson and Gaudet, The People's Choict 129 (1948). A distinction must be made between the communication goals of imparting factual knowledge and of modifying opinions. KLAPPER, op. cit. supra, at pt. 4, p. 10. Inconsistent experiments as to retention of factual material must be distinguished from modification of opinion in which aural presentation has been unanimously found superior to printed material. Id. at pt. 2 , p. 10.

Polls found that employees favored verbal over written communications, with the possible exception of bulletin boards. See Baker, Ballantine \& True 42, 43, 84, 95 (1949). Leaflets or "throwaways" must also be much briefer than the more thorough argumentation in speechmaking. See ILGWU, Handbook of Trade Union Methods 43 (1948); Doob, Public Opinion and Propaganda 461 (1948).

For information on content analysis of arguments, and their effect on worker predispositions, see Bakke, Why Workers Join Unions in BAKKE \& KERR, UN1ONS, MANAGEMent and the Public 41 (1949); Barbash, Labor Unions in Action c.2 (1948); Seidman, London \& Karsh, Why Workers Join Unions, 274 Ansals 75 (Mar. 1951); Whyte, Who Goes Union and Why?, 23 Personnet. J. 215 (1944).

34. Union literature such as union newspapers and pamphlets are usually read only by a comparatively small minority of the employees even in organized plants where they can be mailed to members or distributed by shop stewards with the full cooperation of management. See Barer, Ballantine \& True, 51, 60,112, 131 ; Peters, Communication WITHIN INDUSTRY 132 (1950).

And while the right to distribute union literature on company property has often beell upheld, NLRB v. Le Tourneau Co., 324 U.S. 793 (1945), 157 A.L.R. 1088 (1945); Carolina Mills, Inc., 92 N.L.R.B. 1141, 1142 (1951), enforcement granted, 190 F.2d 675 (4th Cir. 1951) ; distribution may be prohibited where its dissemination is feasible outside plant gates, - Newport News Children's Dress Co., Inc., 91 N.L.R.B. 1521 (1950), especially in order to prevent littering of the premises, Colonial Shirt Corp., 96 N.L.R.B. No. 104 (Oct. 10, 1951) (distinction drawn between a non-working hour ban on literature distribution as compared to ban on solicitation). See note 10 sttpra. In the Bonwit Teller case, while leallets 
added travel are usually poorly attended.35 Comprehensive individual solicitation off the premises is rarely achieved because of cost, time, and difficulty of locating workers at home. ${ }^{36}$ And campaigning by individual employeeorganizers on a catch-as-can basis in the plant, even when not precluded by nosolicitation rules, hardly substitutes for the systematic arguments that can be

were handed out frequently on the sidewalk in front of the store's employee's entrance, Brief for Respondent, pp. 22-3, Bonwit Teller, 96 N.L.R.B. No. 73 (Oct. 4, 1951), adequate coverage of the multitudes of employees caught in the concentrated rush to and from work on a busy New York thoroughfare could hardly be expected.

35. See Baker, Ballantine \& True at 49, 110; Peters, Co:mrumicatton Wrim:i INDUSTRY 131 (1950). Workers whose jobs fill their days are tired and amusement-hungry at night; they are not eager to break away from their families or forego "dates" or relaxation to attend union meetings. Kopald, Democracy and Lcadership in BArse \& Kres, Unions, Managearent and the Public 180 (1949). For British experience, see GoldSteIN, The Goternasent of British Trane UnIoNs 246-61 (1952). Unorganized workers, due to fear of incurring employee disfavor and risking discharge, attend union meetings even more rarely. The union may therefore consider the holding of meetings inadvisable, especially in small cities where everyone is known, until it achieves sufficient strength. ILGWU, HaNDEOOR OF TRADE UMTON Mietrods 10 (1948).

The Bonwit Teller dissent, 96 N.L.R.B. No. 73, at p. 13, cited a Supreme Court diclun: in NLRB v. Stowe Spinning Co., 336 U.S. 226, 230 (1949) (which held that employers may not deny to union the use of only available meeting hall in company town): "We cannot equate a company dominated North Carolina mill town with the vast metropolitan centers where a number of halls are available within easy reach of prospective union members." But in Stowe there was no evidence of employer anti-union speeches on company time and premises. And the Bonwrit Teller issue seems not whether union halls are available in the abstract, but whether such a meeting compares in effectiveness with an on-the-job speech. Moreover, numerical availability of union halls in large cities may be more than counterbalanced by necessary employee travel from widely seattered residential areas. For view in accord with the Bonarit Teller dissent, see Note, Employer's Failure to Permit Union Opportanity to Speak on Company Time and Properly, 100 U. of PA. L. REv. 911, 914 (1952) (which fails to recognize difference between cases involving right of access to company premises for union organizers on their own initiative, which may be governed by a "principle of necessity," and the campaign equality doctrine of Bonaril Teller, put into play only to counterbalance the unfair advantage of unilateral employer on-the-job speechmaking).

Union sound truck speeches at company gates are feasible only where mills and factories employ large numbers of workers and are located in sparsely settled areas with limited avenues of exit. See ILGWU, op. cit. supra, at 111 (1948); cf. Banmasn, LaIor UnIons In ACTron 26 (1948). Aside from dependence on good weather, the speechmalier addresses a rapidly changing group of passing workers ansious to get home from worl: and thus can make only short appeals. See Doob, Public Oprniors and Propagasida 52932 (1948).

36. This was not even mentioned by either the Bonwit Teller dissent or in newsp3per attacks on the decision among feasible alternatives to an employer on-the-job speech. Sce note 21 supra. Neither is it considered by the NLRB in weighing alternatives to union distribution of literature on the premises. See cases cited at note 34 supra. Individual home visits are best utilized at the start of a campaign to convince a few ley workers rather than as an instrument of mass communication. See Brooks, Wues Lacor Organizes 2 (1937). For limitations on home visits, see Barbase, LAcor Unions ni Actro: 26 (1948). 
presented at a mass meeting on working time. ${ }^{37}$ Furthermore, the subtle psychological coercion implicit in forcing an employee to listen to his employer's speech on his premises and on working time ${ }^{38}$ may be counterbalanced by the morale boost of permitting an equal forum to the union spokesman. ${ }^{30}$

Practical considerations equally argue for a broad interpretation of Biltmore. Under any but a flat rule granting the union a reply speech under equivalent conditions, the Board and courts would necessarily have to investigate and evaluate a multitude of dissimilar fact situations. In each case, the availability and effectiveness of alternative union reply methods to an employer on-the-job talk would have to be weighed. ${ }^{40}$ And employers, uncertain of Board criteria and prohibited by the Act from surveillance and interrogation of

37. The major survey of political campaign channels found informal personal conversations more effective than the more formal media of newspapers, radio and formal addresses. Lazarsfeid, Berelson \& Gaudet, The People's Choice 150-1 (1948). But one of the two bases of that conclusion was greater coverage. And the full attendance of an on-the-job speech may undermine the conclusion in the labor context.

At mass meetings, not only does an interaction between the speaker and cach auditor exist but, also, relationships among the listeners through the emotional stimulus of a crowd may reinforce the admonitions and urgings of the speaker. KEX, PoLiticAL PARTIES ANV Pressure Groups 595 (1947).

38. See Note, Employer's Speech dutring Working Hours as Unfair Labor Practice, 14 U. of ChI. L. REv. 104 (1946). Social scientists have noted "deference patterns" predisposing people to respond automatically towards those to whom they have been in the custom of responding. Thus, while they are in the plant, employees customarily obey the instructions of company supervisors and officials. Habitual responses of this type tend to operate whether the employee is responding to the desires of the employer that he should perform some shop operation or that he should pursue some less objective course-such as voting against a certain union. In addition, the display of power inherent in the compulsory audience is itself of considerable psychological significance. See id. at 108-9, and sources cited therein.

39. Alternatively, in extreme cases where employees are brought to the company offices and addressed individually or in small groups, the speech has been entirely condemned, without consideration of potential union replies. Employers' urgings to reject a union "uttered in that locus of final authority in the plant take on a meaning and a significance they do not possess under other circumstances." The resultant subtle cocrcion warrants setting aside the election regardless of the speech content. General Shoe Corp., 97 N.L.R.B. No. 71 (Dec. 12, 1951). Accord, General Shoe Corp., 77 N.L.R.B. 124 (1948), distinguished in Hinde \& Dauch Paper Co., 78 N.L.R.B. 488, 490 (1948); Gray Drug Stores, 79 N.L.R.B. 1140, 1141 (1948) ; Mallinckrodt Chemical Works, 79 N.L.R.B. 1399 (1948). The sole reliance in the Board's most recent case on the previous Gencral Shoc decision implies limitation of its holding to representation cases where $\$ 8(c)$ may not apply. See note 26 supra. For argument that mere setting aside of elections without power to order cessation of condemned conduct may be ineffectual to curb future violations, sce Note, Free Speech and Free Choice in Representation Elections: Effect of Taft-Hartlcy Act $\$ 8(c), 58$ YALE L.J. 165, 174 (1948).

40. For union organizational techniques, see notes $35-8$ supra.

Comparative effectiveness of various media depends on such factors as the number of employees; physical location, structure, and immediate surroundings of the plant or place 
employees to determine the extent and effectiveness of union activities," could not measure their legal obligation to grant a reply. Inevitably, confusion and litigious labor-management strife would flourish.

Bonwit Teller and Biltinore will also shape decisions involving employer campaign media other than on-the-job speeches. ${ }^{22}$ Under the first rationale of Bonwit Teller, anti-union propaganda even by the employer himself is now governed by the restrictions of a company no-solicitation rule. ${ }^{43}$ For example, management's exclusive use of plant bulletin boards for anti-union campaigning has already been held a violation as a discriminatory application of a nosolicitation rule. ${ }^{4}$ Even in the absence of such a rule, the Biltmore doctrine of equal opportunity might demand equivalent union space on plant bulletin boards, a potent campaign medium among employees. ${ }^{25}$ Employers' utilization of communications channels not foreclosed to the union would of course not be subject to a right of reply. Employer-conducted meetings or social gatherings, for example, convening off the plant and in hours other than working

of business; size of the city or town where employees live and comparative lowation of their living quarters to each other, to their place of employment and the union meeting hall; employee level of literacy; presence and extent of company rules restricting union solicitation on company time and premises; timing of emplojee shifts and amount of nonworking time spent by employees at the plant, including lunch hours and rest periods; and amount of money and number of organizers available to the union.

41. Employees have a right to privacy concerning their union activities, and cmployers' attempts to secure such information either indirectly through espionage or surveillance or directly by interrogating the individual employees are held unlawiul. For review of the NLRB rationale and case authority, see Standard-Coosa-Thacher, 85 N.L.R.B. 1358 (1949). Interrogation is unprotected by $\S \&(c)$ because not an expression of "views, arguments, or opinions." It is inherently coercive since it instills fear of subsequent discrimination and hence per se violates $\$$ S(a) (1). Id. at 1362; NLRB v. Minnesota Mining and MIfg. Co., 179 F.2d 323, 326 (Sth Cir. 1950). But cf. NLRB v. Winer, 29 LN. REI. REP. (Labor-Management) 2538, 2541 (7th Cir. 1952); Sax v. NLRB, 171 F.2d 769, 773 (7th Cir. 1949).

42. For surveys of the use of various management media of communication with workers, see Peters, Consasunication Within Industry 42, 43 (1950). See also Baregs, Ballantine \& True cc. 4, 11 ; Baker, Conpany-Wide Understajdino of Imdustrun Relattons Polictes, A Study in Conarunications c. 4 (194S); Barer alid Franter, Personanel Administration and Lazor Relations in Depastisent Stones c. 4 (1950); Gilbertson, Personnei. Policies and Unionisar c. 19 (1950) ; Gracey, Efjectice Com:munications, 29 PERSONNEI J. 86 (1950).

43. See note 17 supra.

44. Cherry Rivet Co., 97 N.L.R.B. No. 212 (Jan. 29, 1952).

45. Bulletin boards are the most commonly used management communication medium. Peters, Comarunication Within Industry 42, 43 (1950). One survey ranked them first as the principal source of employee information on company policies. BAKER, BALLA:itrize. \& TRUE at 26. Builetin boards were chosen by employees as the most popular and convenient medium of management communication. Id. at 42 . Even if the value of the bulletin board is less for argumentation than for dissemination of factual information, see note 33 supra, the great number of employees accustomed to reading posted material makes it important. This is recognized by unions; most collective bargaining agreements contain a stipulation for union use of certain company bulletin boards. PETERs, op. cit. stora, at ju. 
time, can easily be met by equivalent union meetings. ${ }^{40}$ Similarly, employers' letters, leaflets, company newspapers or magazines, and commercial advertising in the local press are open to union rebuttal in equal ways. ${ }^{47}$ If an employer, however, addressed unorganized employees on the premises immediately before or after working time, ${ }^{48}$ singularly suited to convenient attendance, an opportunity to reply under equivalent conditions might well have to be granted the union; campaign equality would be fostered at practically no employer expense or disruption of his business. And in all cases the employer should be free to require that the union communication to the employees precede his own; Biltmore may require only equality of opportunity, not a guarantee to the union of the "last word" in every campaign. 40

Bonzerit Teller and Biltmore do not muzzle employers' "free speech" or emasculate Section 8(c) of the Taft-Hartley Act. True, court affirmance of

46. For suggestion that proper application of an equal opportunity rule would include the right of an employer to address union hall audiences, see Bonwit Teller, 96 N.L.R.B. No. 73, p. 13 (dissenting opinion). But opportunity to invite employees to attend voluntarily a meeting outside of working hours is open to both union and management. The same does not hold true of speeches on company time and premises.

47. For information on the enumerated media, see note 42 supra. Company periodicals are one of the most effective media of communication between management and $\mathrm{cm}$ ployees. See Jones, The Employee Magazine in Successful Industrial Relations, 29 PERSONNEL J. 47 (1951) ; Beach, Employee Magazines Build Morale, id. at 216; Masters, Employee News Publications, 6 PUB. Retations J. 14 (Mar. 1951). Unions may put out their own newspapers or magazines and can compete for reader interest on the same basis as the employer. While union periodicals usually have not been as widely read, improvement of union publications might attract greater audiences. See BAKER, BALLANTINE \& True 36, 51, 112; Peters, Communication Within Industry 132 (1950). Plant news= papers have been successfully used in union organizing drives. BARBASH, LAUOR UNIONS IN ACTion 25 (1948).

But most company periodicals steer away from obvious propagandizing and the controversial subjects involved in an anti-union campaign. See Benson, Employec Newuspapers, 6 Pub. Relations J. 14, 27 (1951) (description of Gen. Shoe Corp. periodical) ; Masters, supra at 16 ; Beach, supra at 217.

Union leaflets and periodicals are probably entitled to the protection of the Bontrit Teller and Biltmore holdings as to distribution privileges on company premises.

48. But cf. Meier \& Frank, 89 N.L.R.B. 1016 (1950) (employer anti-union speech halfhour before store opens to employees not being paid for their time; held privileged prior to Bonzerit Teller, but no union reply request).

While employees must usually be permitted to indulge in union proselytizing during off-hours normally spent on company premises, see note 10 supra, maunagement has not been required to permit organized meetings. Fafner Ball Bearing Co., 26 War Lab. Rep. 308, 311 (1945).

49. See Biltmore dissent, 97 N.L.R.B. No. 128, p. 6: "[U]nions, if they so desire, must now be accorded the privilege of having the last word in an election campaign." The Board opinion indiscriminately uses "right of reply" and "right to hear both sides of the story." But the "right to hear both sides" seems the fundamental basis of the cuse. If no other campaign opportunity is equivalent to an on-the-job speech, a "right to reply" probably simply guarantees campaign equality, not "last words." 
Bonzerit Teller ${ }^{50}$ will dictate caution to employers contemplating on-the-job campaigns; granting an equivalent opportunity to unions would furnish them a potent propaganda device and cost the employer for additional working time lost. ${ }^{51}$ But although the number of employer speeches may thus be curtailed, ${ }^{52}$ the employer continues free to express his non-coercive opinions onthe-job to employees-provided only that his monopoly utilization of a most effective campaign medium is shared. ${ }^{53}$ And if he is unwilling to permit a

50. Bonzuit Teller, Inc. v. NLRB, No. 22208 (2d Cir.), was argucd before Judges Frank, A. Hand, and Swan on April 14, 1952, and is now awaiting decision.

Biltmore and its sequels not involving unfair labor practice charges probably will not be appealed. There is no direct judicial review of representation cases. Courts of Appeals may review only cease and desist orders. A.F.L. v. NLRB, $30 S$ U.S. 401 (1940). However, if the employer refuses to bargain collectively after a union victory in a new election or the setting aside of a decertification election, an appealable unfair labor practice procceding might follow under $\$ \$(a)(5)$, permitting collateral attack on the Board ruling setting aside the original election. Despite House attempts to permit direct court reviev of representation proceedings, the practice remained unchanged by the Taft-Hartley Act. Conference Report, H.R. KEP. No. 510, S0th Cong., 1st Sess. 56 (1947). See Note, $5 S$ YALE L.J. 165, 174 (1948).

51. Whether the union must pay for its use of company time and facilities to reply to the employer on-the-job speech was thought unsettled. Note, Employer Who Addresses Captive Audience .Iust Give Union Equal Opportunity, 65 HAsv. L. Rev. 695,696 (1951). But Bonzit Teller did not mention compensation nor did subsequent "equal opportunity" cases. And unions do not pay rent for soliciting members on company premises or reimburse the employer for paid lunch and rest periods utilized for union organizing activities. See note 10 supra. If the meetings took place at the union's initiative, compensation might be validly demanded, since on-the-job speeches involve production time. In all "cqual opportunity" cases, however, the employer's initiative provokes the union reply and should take into account these consequences. Moreover, argument for reimbursement assumes some feasible system of determining and allocating the variable costs of the additional production or sales time lost by the union reply could be devised.

52. See 28 LAB. ReI. ReP. (Analysis) 105, 108 (Oct. \&, 1951).

53. The new "equal opportunity" rule differs sharply from discredited "captive audience" doctrine condemned by $\S 8(c)$ and its legislative history. See note 6 supra. Whether employees are "forced to listen" to the employer speech is now immaterial. See note 13 supra. The employer is not proscribed from on-the-job speechmaking, and the Board made no finding that an employer's speech on company time and property is coercive. See notes 39 and 40 supra. "We do not proscribe, nor find illegal what the Respondent said, or the manner in which it assembled its audience. We are concerned with what the Respondent refused to do... We leave the Respondent free to exercise fully its right of free specch. We say only that when it chose to speak under the circumstances involved here, then ... it could not lawfully deny the union's reasonable request for an opportunity to reply under the same circumstances." Bonwit Teller, 96 N.L.R.B. No. 73, at p. 10.

For an analogous requirement of "equal opportunity" for all candidates in the use of radio facilities in an election campaign, see Federal Cosmunications Acr, 44 STAr. 1083 (1934), 47 U.S.C. $\$ 315$ (1946); Note, 61 YALE L.J. 87 (1952). The same requirement would apply where the station owner himself is a candidate. No obligation ty accept campaign speeches initially is imposed on the station owner. Id. at SS. The impusition of such a requirement on radio stems from the limited availability of radio frequencies. Sec $\mathrm{Na}$ - 
union reply speech on company premises and time, he must merely limit himself to campaign methods open to unions as well.

tional Broadcasting Co. v. United States, 319 U.S. 190, 226 (1943). Scuttling a prior policy of forbidding station editorialization, Mayflower Broadcasting Corp., 8 F.C.C. 333 (1940), the FCC now permits the licensee to express his views on all issues, provided the overall treatment of any issue includes fair presentation of all viewpoints. Editorializing by Broadcast Licensee, 1 PIKE \& Fischer RAdio REc. 91, 201, 212 (1949); Note, 59 YALE L.J. 759 (1949).

After this Note went to press, the Second Circuit decided Bonwit Teller. Bonwit Teller v. NLRB, No. 22208, 2d Cir., June 17, 1952. The majority apinion agreed with the Board that the employer had applied its own no-solicitation rule discriminatorily when it conducted an anti-union campaign "on the same premises to which the Union was denied access; if it should be otherwise, the practical advantage to the employer . . . would constitute a serious interference with the right of his employees to organize." The dissent disagreed with the majority's statement that "neither $\S 8$ (c) nor any issue of 'employer frec specch' is involved." It contended that $\S 8$ (c) entitled the employer to make on-the-job speeches even where a no-solicitation rule was in effect. Both opinions, however, rejected the broader rationale of equal opportunity, the majority declaring that "[i]f Bonwit Teller were to abandon [the no-solicitation] rule, we do not think it would then be required to accord the Union a similar opportunity to address the employees each time [the employer] made at1 anti-union speech ... so long as the avenues of communication are kept open to both sides." Thus the court ruled the Board's order "too broadly drawn," denied enforcement, and " remanded for modification. The decision, though not referring to Bilmore, flatly contradicted that NLRB ruling, drawing its status into doubt. 